\title{
Historical Review and Revelation of the First Master Plan of Xi'an City under the Influence of the Soviet Planning Model
}

\author{
Ying Shu \\ University of Tsukuba, Tsukuba, Japan \\ Email: s1730143@s.tsukuba.ac.jp
}

How to cite this paper: Shu, Y. (2021). Historical Review and Revelation of the First Master Plan of Xi'an City under the Influence of the Soviet Planning Model. Current Urban Studies, 9, 720-729. https://doi.org/10.4236/cus.2021.94042

Received: October 5, 2021

Accepted: December 5, 2021

Published: December 8, 2021

Copyright (๑) 2021 by author(s) and Scientific Research Publishing Inc. This work is licensed under the Creative Commons Attribution International License (CC BY 4.0).

http://creativecommons.org/licenses/by/4.0/

\section{(c) (i) Open Access}

\begin{abstract}
Xi'an, an ancient city with a thousand-year history, was designated as one of the eight key industrial cities in 1952. Due to the above reason, the Soviet Union planning model was introduced into Xi'an by Soviet planners and Xi'an began to transform from a traditional city to a modern industrial city. On the basis of relevant historical materials, this paper firstly reviews the compilation process and content of the first Master Plan of Xi'an city with the guidance of Soviet and Chinese planning professionals. Moreover, the paper examines how Soviet urban planning theories were introduced into Xi'an and their positive and negative effects. Finally, the authors discuss the contribution and role of Soviet and Chinese experts in the procedure.
\end{abstract}

\section{Keywords}

Soviet Experts, Xi'an First Master Plan, Industrial City

\section{Introduction}

After the establishment of the People's Republic of China in 1949, the domestic economy had been fully restored and the social order was relatively stable. With the assistance of the Soviet Union, many urban planning and construction activities were carried out nationwide. Hence, this period was called "the first spring" of the city planning history of new China. Soviet Union aid played a key role in Chinese urban planning development during this period. It seems needless to say, in the early days of the founding of the People's Republic of China, we began to learn unilateral politics and diplomacy from the Soviet Union in different aspects, including urban planning. However, judging from the existing related researches, most of them are focused on the urban structure, or research on indus- 
trial distribution, neglect some details in the planning process. Meanwhile, some research questions are ignored: how did Soviet experts guide China's urban planning work? In what ways did they help and develop Chinese urban planning?

\section{Soviet Union Aid and Key Industrial Cities}

\subsection{Soviet Aid to China}

In the early times of the founding of the People's Republic of China, the nation was allied with the Soviet Union and implemented a unilateral diplomacy, which brought Soviet supports in all aspects of country. Moreover, China carried out a large active to learn from the Soviet Union. The assistance of the Soviet Union stands as an important contribution to Chinese industrial system and urban development. From 1950-1953, there were 1093 Soviet experts came to mainland of China and were assigned to work for 500 to 600 institutions or companies in almost 16 Chinese cities. The aid activity played an important role in guiding economic construction and scientific research in China in 1950s-1960s. Compared with reading books and field trips, by the way of communicating and working with Soviet experts could learn more skills and experience effectively. It helped China to improve national construction at that time.

\subsection{Key Industrial Cities}

From September $1^{\text {st }}$ to $9^{\text {th }}$ in 1952, the Central Finance Committee held the first national urban construction conference, and it had representatives participating in that conference from six regional finance committees and 11 cities including Beijing, Tianjin, Chongqing, and Xi'an, etc. The meeting proposed that urban construction should be carried out according to the national long-term plan, by step for different cities, overcoming blindness. Urban planning should meet the needs of large-scale socialist construction under the unified leadership of the state. The conference also told that the governmental policy focus on developing heavy industries and urban planning and construction which heavy industries located in during the First Five-Year Plan period. In the year of 1953, with the Five-Year Plan has been started, the national economy has been started to recovery. According to the significance, cities in whole country are divided into four categories in order to determine the construction priority. Because it is could conducive to concentrated financial and material resources. For this reason, Xi'an was identified by the state government as one of the eight key industrial cities in the first category. This is also the first time Xi'an has received national decision-making support in the history of urban construction since the end of the civil war.

\section{3. "156" Projects}

During the "Five-Year Plan" period, the Soviet Union helped China to build "156" industrial projects to develop its heavy industry, including energy, machinery, and raw materials and so on. 
Xi'an is the city which has the largest number of " 156 " projects aided by the Soviet Union. According to the national industrial layout, the resources and traffic conditions, the state decided to build 14 industrial projects in Xi'an. Through several meetings and discussions with experts from the Soviet Union, it was finally determined that the " 156 projects" were located in the east and west areas outside the old city of Xi'an. The planning idea wanted to protect the urban heritage of the old city and developing the industry on both wings. Thus, this planning idea is the guideline for the preparation of Xi'an first master plan.

\section{Process of First Master Plan of Xi'an City}

The first master plan of Xi'an city has begun in 1950, earlier than other cities. At that time, a survey team was organized to carry out topographic surveys in urban areas, and social democrats, university professors, engineering and technical personnel, and relevant organizations were formed an urban planning committees to research and make formulate overall plans (Urban Construction Committee of Xi'an Government, 1954a) (Figure 1).

However, only two civil and hydraulic engineers from the Municipal Construction Bureau are responsible for the planning and design. Because of lacking special urban planning knowledge and experience, they had to formulate more than a dozen drafts by imitating the urban planning of the United Kingdom, the United States, and Japan, but its planning principles and skills are quite incorrect. For example, mixing with industrial and residential areas, only focusing on commercial areas, without necessary parks, green spaces, streets, squares and systematic. From 1951, Xi'an government asked the Central Finance Committee for instructions, invited Beijing Metropolitan Committee and Tsinghua University professors for some advice, but it did not bring good results (Urban Construction Committee of Xi'an Government, 1954a). From this, we can infer that Xi'an

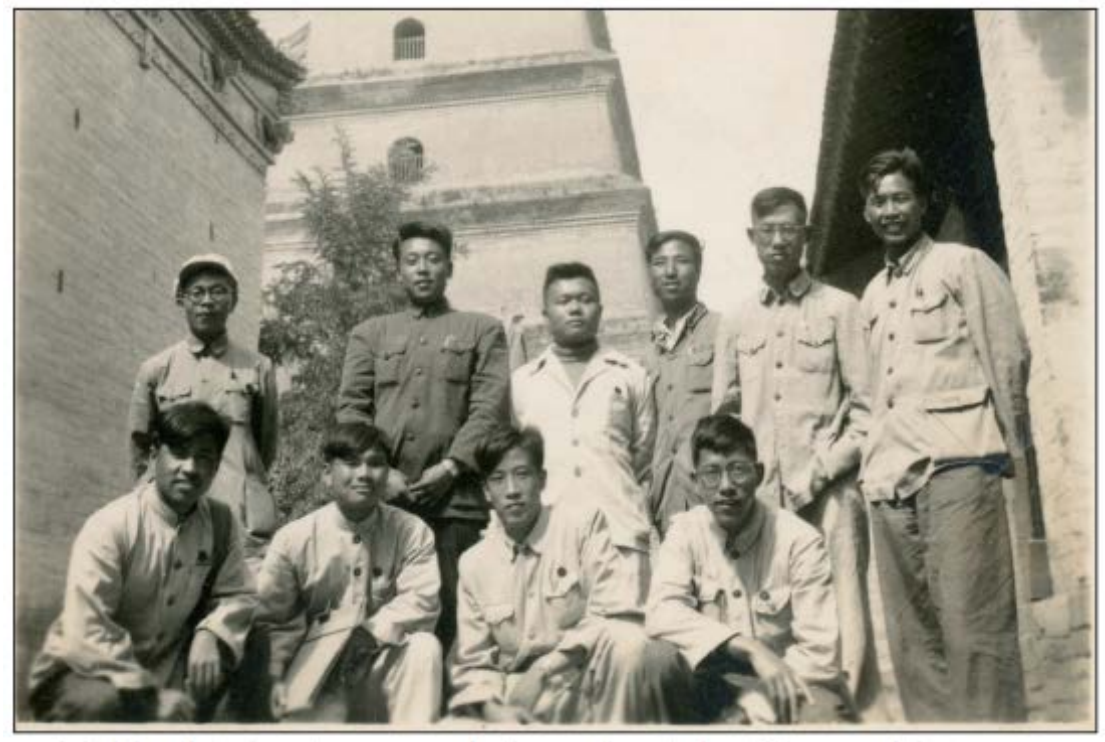

Figure 1. Photo of the staff of the Xi'an Planning Working Group in 1953 (Li, 2019). 
was faced with a shortage of technical personnel in the early stages of plan preparation, which resulted in the planning process was not being able to proceed smoothly.

In September 1952, the Central Finance Committee held a symposium on urban work. During the meeting, the Xi'an Urban Construction Committee reported their planning work and was advised several times by Soviet expert, A. C. МҮХИН. The direction and ideas of urban planning were gradually clear, when we can realize that they have a breakthrough in planning of Xi'an city.

$\mathrm{Xi}$ 'an is the city with the largest number of "156" projects by the Soviet Union. Thus, its urban planning is a "pilot" for the whole country. Its planning is also selected as "study case" for other cities in China (Li, 2017). Therefore, Xi'an became an important object for Soviet experts to guide urban planning work.

Soviet experts have planned and discussed the draft of the Xi'an first Master Plan on March 20, July 9, July 28, and August 29 in the year of 1953. Among them, the first talked expert was А.С.МҮХИН, a former academician of the Soviet Academy of Building Sciences, who went to Xi'an to conduct an investigation (Urban Construction Committee of Xi'an Government, 1953). Another expert who participated in the last meetings was БАРАГИН, who previously worked at the Leningrad Urban Design Institute (Figure 2).

Soviet experts pointed out that the preliminary preparation is insufficient, and it is necessary to offer the urban economic development vision, current situation map. After that, Soviet experts commented and guided the current situation map, green space layout, road design, industrial and residential layout in the draft plan. Furthermore, they focused on explaining some blocks layout patterns and spatial design methods. Finally, Soviet experts specified the content and relevant requirements of the planning drawings, planning description and other

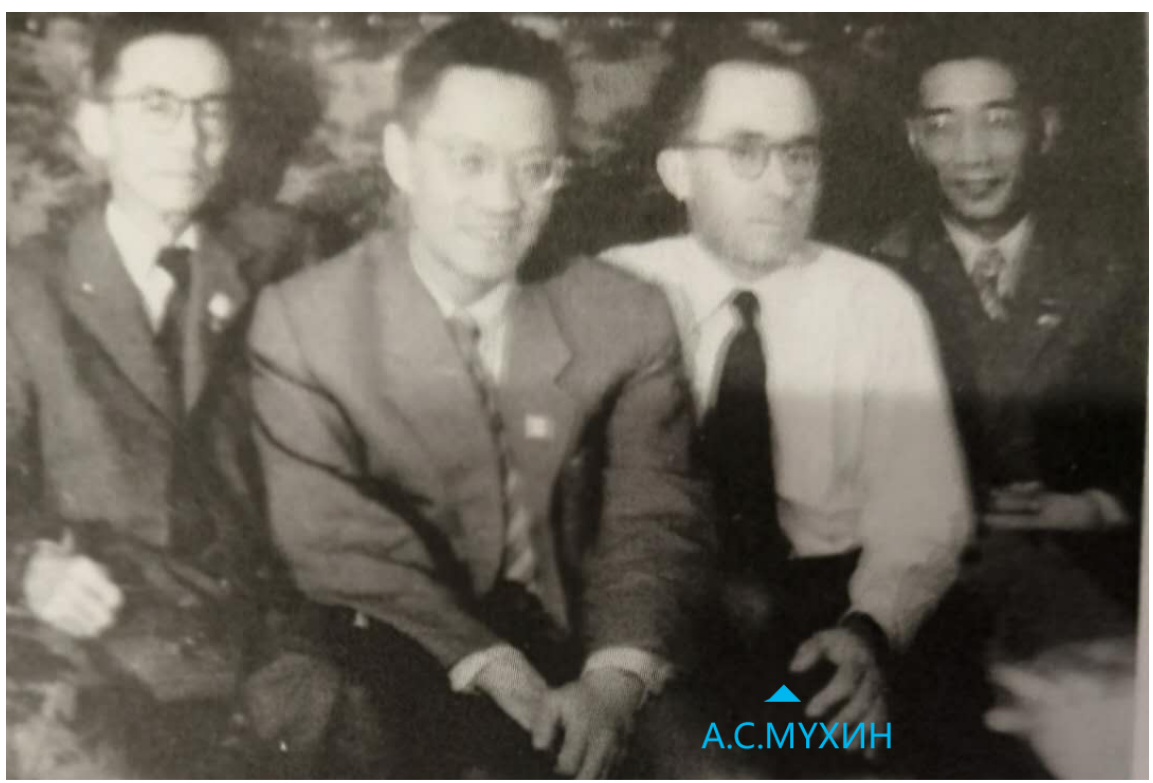

Figure 2. Group photo of Chinese planners and Soviet expert, А.С.МҮХИН (the second person from right) (Li, 2019). 
relevant planning approval materials (Urban Construction Committee of Xi'an Government, 1957).

On December 11, 1954, Xi'an First Master Plan, as one of the first achievements since the founding of the People's Republic of China, was officially approved.

\section{Characteristics of First Master Plan of Xi'an City}

\subsection{Protection of the Old City and Cultural Heritage}

Protection of the old city and Han and Tang dynasties heritage in north are the distinctive features of Xi'an first master plan. The plan designed a pattern which is industrial areas in the eastern and western side of old city, administrative, commercial and residential areas in the old city. The plan reserve the old city area and existing railways, highways and other municipal facilities as a fundamental principle. The plan decided that the urban area would be extend southward based on an original area, and expansion area located from east of the Luo River to the west of Zao River, the north of the city is a development reserve area (Urban Construction Committee of Xi'an Government, 1954b).

On the other hand, the State Council and the Ministry of Culture indicated that planners should protect historical and cultural heritages, particularly, industrial site should avoid the old city and the ancient city ruins of Han and Tang dynasty in the north of the old city (Zhou, 2004).

Therefore, after studied the historical data of Xi'an, by combining theory with practice, the planners has confirmed a settlement: protect and reuse the old city, industrial areas on the east and west sides of the city, the administrative center in the old city area, the southern suburb is cultural and educational areas, and the north area of the railway is used for a warehouse and development reserve area. Every area is connected by a half-octagonal circular radial road system (Figure 3).

\subsection{Inheritance of Traditional City Pattern}

The first master plan of Xi'an continued the traditional road grid with balanced symmetry and checkerboard pattern. The planned trunk road system is centered on the old city. The east-west and north-south cross streets are retained and extended (Urban Construction Committee of Xi'an Government, 1954b). In addition to the east-west and north-south arterial roads, and a number of ring roads are planned in central area. And they planned a road from train station to the Dayan Tower, which was a landmark and build in Tang dynasty. Each arterial road is connected to the social activities of each square. The plan studies Chang'an city structure of the Tang Dynasty and maintained the traditional pattern and scale, as well as the characteristics of architectural art (Han, 1982).

In terms of inheriting the traditional urban pattern, according to Mr. Ganzhi Zhou, by consulting with Mr. Liangzhang $\mathrm{Wu}$ and Zongjiang Mo, and studying the Li-fang urban system of traditional Xi'an city in Tang dynasty, he finally 


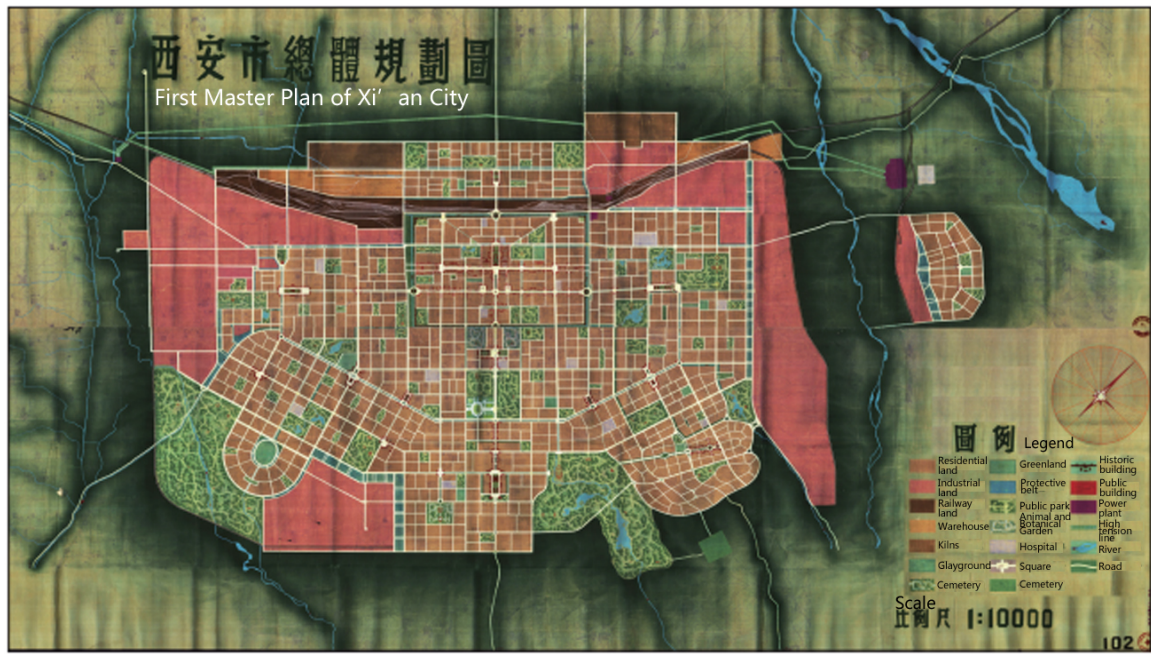

Figure 3. First master plan of Xi'an city (vision plan, Xi'an Government, 1954a).

decided the idea which is "retaining the traditional checkerboard urban form". (Zhou, 2004) It can be seen that in the planning work of Xi'an, the ideology and design ideas of the planners played a subjective role in the formation of the spatial planning layout, while Soviet experts and Chinese scholars played a certain guiding role.

\subsection{The Soviet Pattern: A Combination of Basic Principles and China's Actual Conditions}

For the urban planning works in the early days of new China, it is often evaluated as "copying the planning and construction model of the Soviet Union" (Wei, 2014) in many literature. According to historical meeting records over Xi'an first master plan, the guidance of Soviet experts on planning, such as planning guidelines, planning content, planning procedures and methods, is of course based on some practical experience and planning work models of Soviet city construction, so the whole guidance process by Soviet experts is also an import process of Soviet planning model to China.

It is worth noting, however, that the Soviet experts did not just apply Soviet experiences mechanically, but started from some basic principles of the planning work itself, both guiding "how", also telling "why", and then teaching "how to do it Better". In the conversation, the Soviet experience was mainly discussed in terms of planning standards. When introducing this, Soviet experts emphasized that they should be combined with China's actual conditions and actual facts of Xi'an: by the Soviet Union standards, the maximum service radius of each public park is $1.5 \mathrm{~km}$. Of course, this is not to use a geometrical method with a radius of $1.5 \mathrm{~km}$ as the park location, but should consider the actual situation and conditions: 1) public green belts and space; 2) river and lake; 3) hills and lowlands 4) Places of historic interest, these are usable conditions. As the Soviet experts said: planning work should not straightly copy the Soviet model but be determined in 
accordance with the actual situation in China. It can be seen that the guidance of Soviet experts on planning is more based on how to do a good job of planning. Its foothold is mainly in the scientific system of planning rather than dogmatism. So it is not accurate to simply use the Soviet model to evaluate (Urban Construction Committee of Xi'an Government, 1957).

\subsection{More Comprehensive Economic Concepts}

Due to the economical difficulty in the early days of new China, the government launched many increasing productions and saving resources movements and initiated many economic measures, such as add an additional layer on each existent building instead of build new buildings. From the conversation records, it can be seen that Soviet experts paid great attention to the issue of economy when guiding the planning work while the economic principle is also among the three planning principles. But in terms of economy, Soviet experts have different perspectives. They believe that the existing number of high-rise buildings is sufficient and no additional construction is needed. Moreover, it is wrong to simply talk about the economic view of architecture. Architectural design must take into account various factors, such as comfort and aesthetics. Experts have suggested that the balance between the number of floors and the cost should be considered first, then the construction cost of urban infrastructure should also be noticed, and the cost of building materials should be paid attention to at the beginning of construction to avoid rework (Figure 4).

In many other respects, Soviet experts also emphasized economic efficiency. For example, they mentioned that whether changing the current road system is an economic issue, which should be considered from the perspective of economy rather than composition. The cost of demolishing houses and building new sewers should be considered. Moreover, about the size of public squares, they indicated that although Moscow's red square is 5 hectares, squares in Beijing are 6 hectares, 3 - 4 hectares is suitable for Xi'an. As experts said, "large squares will cause many environment problems such as dust and surrounding buildings will appear to be small." It is not difficult to understand that compared with the relatively single saving orientation of the production increase and saving movement, the guidance of Soviet experts reflects a more comprehensive and economic concept.

\subsection{Urban Design Led by Architecture and Engineering}

The planning work in the early days of new China was an important foundation for the start-up of the planning industry in New China, and also the source for the continuous development of urban planning for the last 60 years. From the guidance of Soviet experts on the planning of Xi'an city, the knowledge hierarchy derived from architecture and engineering play a dominant role, such as land use, spatial layout, the economic principle of urban planning, and economic 


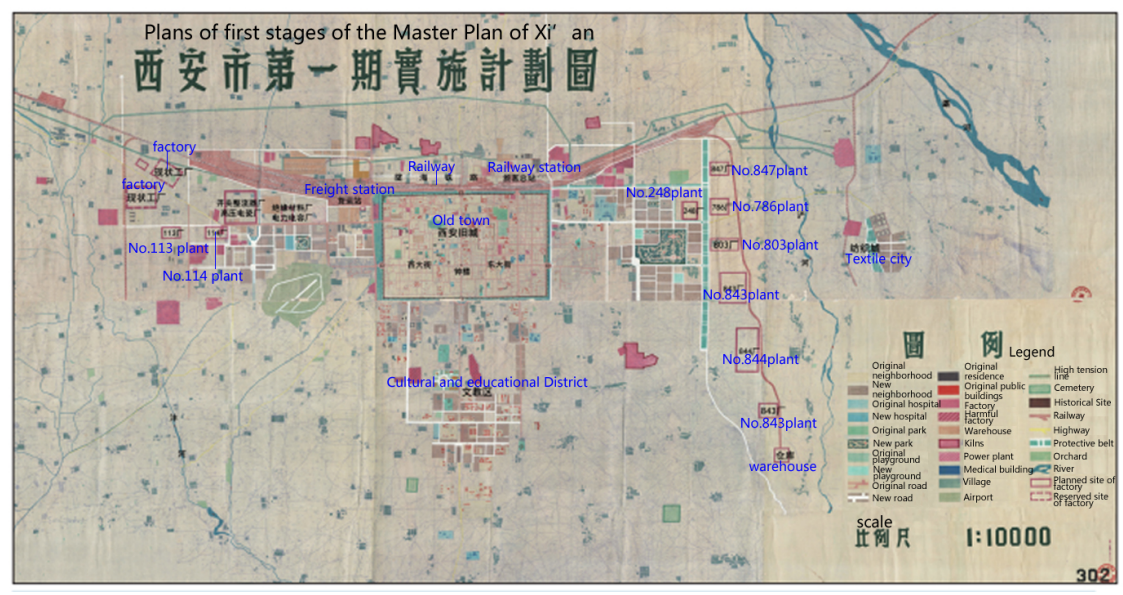

Figure 4. Plans of first stages of the master plan of Xi'an (Xi'an Government, 1954b).

development policy, etc. Such hierarchy is from the Soviet Union model, which emphasized that urban planning as the continuity of the National Economic Plan. In terms of planning work methods, Soviet experts not only talked about the basic procedures of planning and the main issues that should be paid attention, but also introduced the principles and techniques of design drawing, and even included some scientific principles of design work. Taking residential areas planning as an example, Soviet experts have pointed out that some planning factors such as the size and shape of lands have different impacts on the construction investment: "The larger the land area, the less the construction cost of road." For these planning and design principles, planners can obtain corresponding knowledge and "awareness" when their planning experiences have accumulated to a certain degree. At that time, they will also achieve savings by improving planning and design. It was undoubtedly a very advanced planning idea under that situation. Understanding of these characteristics of the planning work in that period will help us to get the context of urban planning in New China.

\section{Evaluation of Soviet Experts’ Work}

The "Soviet model" is an ideal blueprint-type plan that guarantees the implementation of the "continuation of the national economic plan", has a strong industrialist rationalism. The theory and practice of the Soviet Union urban planning mode enabled China to complete the construction of the industrial city system in a short time.

\subsection{Positive Influence}

In Generally, Soviet experts' guidance on planning is comprehensive, systematic and in-depth. It contains both a large number of professional content and some political content (such as socialist city planning ideas), as well as some planning methods, planning attitudes and other content (such as suggestions for collecting basic information).

From the perspective of professional content, the guidance of Soviet experts 
includes not only macro-level concepts such as planning guidelines, scientific basis and basic principles, but also operational contents such as planning documents, preparation contents, planning standards, and technical methods. In addition, the Soviet experts also introduced in-depth institutional construction issues such as the signing of departmental agreements, as well as detailed issues such as drawing methods and performance techniques. The guidance of Soviet experts has been tireless, meticulous, and has taken into account the contradictions between theory and practice, long-term vision and recent times, Soviet experience and China's reality.

The idea of "serving for industrial production" and "serving for the people" runs through whole planning process. The introduction of the Soviet Union's industrial construction system solved the production and living needs of the working class. In the functional zoning layout of urban land, location of industrial zones was considered firstly, and sufficient construction land was well reserved; the living and residential areas are distributed as the main function, so that the urban people can avoid industrial pollution and enjoy ample green space; the quota indicators are comprehensive.

\subsection{Negative Influence}

Because of the over-emphasis on heavy industry and defense industry, other urban functions have been ignored, resulting in an imbalance in the proportion of urban land. In particular, the excessive proportion of industrial land has led to a smaller proportion of urban residential land and public facilities.

In the process of Xi'an city planning implementation, although the preliminary plan in the form of "blueprint" has a perfect composition, it is difficult to implement due to its high requirements on engineering technology and economic budget, large number of relocation of existing residents and large-scale leveling of the site.

The design of the planned quota of one thousand and the construction quota, which completely copied the Soviet standard, did not conform to the actual situation. For example, Xi'an adopted the standard, which is each citizen have $15 \mathrm{~m}^{2}$ dwelling area and green land at least, respectively, and set up sanitary protective belts for industrial enterprises in accordance with the Soviet sanitary protection standards. As far as these standards are concerned, they are mostly based on good original intentions such as hygiene and health, and have certain scientific basis. However, compared with China's weak economic conditions at that time, they seem to be somewhat idealized.

\section{Conclusion}

The guidance of Soviet experts on the planning work of Xi'an not only affected the construction and development of Xi'an, but also accumulated valuable practical experience for the planning work of other cities, and accelerated the construction of the national urban planning system. Taking the system of depart- 
mental planning agreement as an example, on the basis of the practical experience in Xi'an, the state planning commission, in order to strengthen the organizational review of the preliminary planning of new industrial cities, issued the notice of agreement documents on major issues in urban planning in October 1954. In three cases, it made clear provisions on the agreement between urban planning and relevant departments, thus raising the system of planning agreement proposed by the Soviet experts to the level of the national system. More importantly, under the guidance of the Soviet experts, a large number of professional and technical personnel-the first generation of urban planners in new Chinawere trained in a short time, which is an important technical guarantee for the vigorous development of the planning industry. In short, in understanding the issues related to the development of urban planning in the early days of new China, we must not forget the mentor-an indelible important contribution made by Soviet experts.

\section{Conflicts of Interest}

No potential conflicts of interest were reported by the author.

\section{References}

Han, J. (1982). Protection of the Ancient City of Xi'an. Journal of Architecture, 10, 8-13.

Li, H. (2019). The Planning of Eight Key New Industrial Cities: Urban Planning History of P.R. China in 1950s (p. 90). China Construction Industry Press.

Li, H. (2017). Interview with the First Generation of Urban Planners in New China (p. 52). China Construction Industry Press.

Urban Construction Committee of Xi'an Government (1953). Report on Expert Opinions of Soviet Cities. Archives of Xi'an Archives, File No. 2.

Urban Construction Committee of Xi'an Government (1954a). Summary Report on the Work of Xi'an's First Master Plan. Archives of China Academy of Urban Planning and Design, File No. 0970, 68-99.

Urban Construction Committee of Xi'an Government (1954b). Xi'an Urban Master Planning and Design Specification. Archives Office, China Academy of Urban Planning and Design, File No. 0925, 35.

Urban Construction Committee of Xi'an Government (1957). Report on the Work of Xi'an's First Master Plan, Summary Report and Experts Proposed Pooling of Xi'an's Planning in 1953-1956. Archives of China Academy of Urban Planning and Design, File No. 0946, 171-217.

Wei, D. (2014) Urban Planning History and Theory 01 (pp. 119-137). Southeast University Press.

Xi'an Government (1954a). The Map of First Master Plan of Xi'an City. Archives of China Urban Planning and Design Institute, File No. 0967.

Xi'an Government (1954b). The Map of First Stages of the Master Plan. Archives of China Urban Planning and Design Institute, File No. 0967.

Zhou, G. Z. (2004). Recall of Xi'an's First Round Urban Master Plan. Urban Development Research, 3, 1-6. 